Kinestetik : Jurnal Ilmiah Pendidikan Jasmani 5 (2) (2021)

Kinestetik : Jurnal Ilmiah Pendidikan Jasmani

https://ejournal.unib.ac.id/index.php/kinestetik/index

DOI : 10.33369/jk.v5i2.17817

\title{
THE EFFECT OF MULTIBALL TRAINING ON THE PRECISION OF FOREHAND BUTTON IN TABLE TENNIS EXTRACURRICULAR STUDENTS OF SMA NEGERI 7 BENGKULU CITY
}

\author{
Alexon $^{1 *}$, Defliyanto ${ }^{2}$, Dian Pujianto ${ }^{3}$, Ari Sutisyana ${ }^{4}$, Angga Burlian ${ }^{5}$ \\ ${ }^{12345}$ Physical Education Study Program, Universitas Bengkulu, Bengkulu City, Indonesia
}

\section{Article Info}

Received :June 2021

Revised : June 2021

Accepted : June 2021

Available online: June 2021

Keywords:

forehand, multiball, table tennis.

\begin{abstract}
This study aims to determine the effect of multiball training on forehand accuracy in table tennis extracurricular students. This research was conducted at SMA Negeri 7 Bengkulu City. In this study using a Quasi experimental method (quasi experimental). The design used was one group pretest posttest design, that is, pretest was done before treatment and posttest was done after treatment. The treatment given was multiball training with various variations. This design requires a group without comparison. The population in this study amounted to 16 students, the sample selection used a total sampling technique where the entire population was taken as the research sample. The data collection technique in this study was the direct test method, namely using the $1 \mathrm{x}$ pretest, $14 \mathrm{x}$ trials and $1 \mathrm{x}$ posttest in table tennis. The statistical prerequisite test fulfills the requirements that the data is normally distributed based on statistical counts. The results obtained from the data $t$ count 142.13 and $t$ table 2.13145 with a level of $=0.05$. The results of this study indicate that there is an effect of multiball training on forehand accuracy in table tennis extracurricular students at SMA Negeri 7 Bengkulu City, so it can be concluded that multiball training affects the improvement of forehand accuracy in table tennis extracurricular students.
\end{abstract}




\section{INTRODUCTION}

Physical education, health and recreation are teaching programs that are very important in the formation of students' fitness. One of them is table tennis, table tennis is a type of game sport that is popular in the world, even in Indonesia itself, this sport is no stranger to society (Santi, 2018). Table tennis can be played and can be enjoyed by all family members, because in addition to being beneficial for health, this sport can provide exercise and entertainment to players of all age levels, whether at an early age, teenagers, adults or the elderly. physical conditions in sports such as strength, endurance, muscular power, speed, coordination, flexibility, one of which is in SMA Negeri 7 Bengkulu City.

Extracurricular activities are a series of teaching and learning activities outside the programmed lesson hours, which are intended to increase students' horizons, cultivate talents and interests as well as the spirit of community service. For example: the Youth Red Cross (PMR) activity is a form of activity that develops many humanitarian activities, including holding environmental hygiene actions, providing assistance to people affected by disasters, providing health and so on (Novianty Djafri, 2018). In this extracurricular, students are taught how to hit with several strokes in table tennis. It must be understood that an extracurricular curriculum program still requires teacher intervention and creativity who will operationalize it in the teaching and learning process (Ubaidah Sity, 2017). Extracurricular activities are activities carried out in developing certain aspects of what is found in the current curriculum, including those relating to how the actual application of the knowledge learned by students in accordance with the demands of their life needs and the surrounding environment, is shown to help the development of students, according to their needs, potential, talents, and interests through activities that are specifically organized by students and/or educational staff who are capable and authorized in schools (Wiyani, 2013).

It is undeniable that the training process is monotonous, so that students will experience problems. Where the lack of creativity of a coach in packaging the training program so that there is still a lack of forehand hitting techniques.

Researchers will give multiball exercises to students, lExercise or training is the application of a plan to improve the ability to exercise which contains theoretical and practical material, methods and implementation rules in accordance with the goals and targets to be stamped.ai (Sukadiyanto \& Muluk, 2011), there are some physical exercises given, according to Sadoso in Hasanah, (2013), According to Harsono in Mulia 2013 that "Exercise is a systematic process of practicing or working that is done repeatedly, with increasing days. The purpose of training is to help an athlete or a sports team improve their skills or achievements as much as possible by considering various aspects of training that must be considered, including physical exercise, technique, tactics, and mental training (Hadi in Sulaksono, 2015).

Extracurricular Goals According to the Regulation of the Minister of Education and Culture of the Republic of Indonesia Number 62 of 2014 concerning Extracurricular Activities paragraph (2), namely: Extracurricular activities are organized with the aim of developing the potential, talents, interests, abilities, personality, cooperation, and independence of 
students optimally in the context of support the achievement of national education goals.

Based on the explanation of table tennis at SMA Negeri 7 Bengkulu City above, the researchers plan to train students by using methods that can improve the accuracy of forehand strokes through multiball exercises with the title of research the effect of mutiball training on the ability of table tennis forehand accuracy in extracurricular participants at SMA Negeri 7 Bengkulu City. The hypotheses in this study are:

H1 : There is a training effect mutiball on the ability of table tennis forehand accuracy in extracurricular participants at SMA Negeri 7 Bengkulu City.

HO : There is no effect of mutiball training on the ability of table tennis forehand accuracy in extracurricular participants at SMA Negeri 7 Bengkulu City.

\section{METHODS}

This research was conducted on table tennis extracurricular students at SMA Negeri 7 Bengkulu City which is located at Lingkar Barat sub-district, Bengkulu City, the research was conducted for 16 meetings. until 16.30 WIB which is for 1.5 hours.

In this research, the type of research used is quasi-experimental research (quasi-experimental).This experimental research method is recognized as the most scientific research of all types of research. Because researchers manipulate treatments that cause something to happen. This is in contrast to other types of research where data phenomena are obtained from the past which are observed and analyzed (Pujianto, 2013). The design used was a one group pretest posttest design, namely experimental research conducted on only one group selected at random and no stability and clarity test of the group's condition was carried out before being given a group. According to Arikunto (2010) Variables are things that are the object of research, which are looked at in a research activity that shows variations, both quantitatively and qualitatively.

The design of this study was measured by a pretest which was conducted before being given treatment and a posttest which was conducted after being given treatment. This sample was given treatment for 16 meetings. The training given is for 4 weeks, each week is given 4 meetings. There the researchers will see, after being treated for 14 meetings whether it has an effect on the accuracy of students' forehand strokes.

The forehand is the main attack technique in the game of table tennis (Hsin-Hsueh Huang, 2012) in . The forehand stroke is a basic technique of table tennis where the palm of the hand holding the bet faces forward when hitting the ball, the hands and elbows form an angle of 900, so the position of the bet is slightly perpendicular (Juniarisca and Andrijanto, 2017).

\section{Sampling Procedure}

According to Sugiyono (2013: 80) "population is a generalization area consisting of objects that have certain quantities and characteristics determined by research to be studied and then drawn conclusions". The population in this study were members or participants of table tennis extracurricular at SMA Negeri 7 Bengkulu City, totaling 16 students. The sampling technique in this research is total purposive, this technique is based on a specific purpose. Total purposive technique is a sampling technique with certain considerations (Sugiyono, 2013) 
In this research, the type of research used is quasi-experimental research (quasi-experimental). The design used was a one group pretest posttest design, namely experimental research conducted on only one group selected at random and no group stability and clarity tests were carried out before being given a group. The design of this study was measured by a pretest which was conducted before being given treatment and a posttest which was conducted after being given treatment. This research was conducted at SMA Negeri 7 Bengkulu City. The study was conducted on October 05 November 05, 2020.

\section{Materials and Equipment}

The materials and tools used in the research process were table tennis tables, bets, nets, balls, and sports equipment used during the treatment which was carried out during the second meeting to the fifteenth meeting. The tests used were pretest and posttest, which were conducted at the initial meeting (first meeting for pretest and last meeting (sixteen) for posttest scores. Research conducted at SMA Negeri 7 Koa Bengkulu which was conducted on table tennis extracurricular was carried out in 16 meetings with the first meeting, namely the pretest of the second meeting to the 15 th meeting, namely the treatment given to students, namely:In the first treatment, students were asked to do exercises wrist curlusing dumbbells (milk cans or syrup bottles) step by step, students sit on benches. Holding dumbbells with palms facing up. Use only your forearm muscles to lift the dumbbells toward your wrists without bending your elbows. In the second treatmentstudents do wrist rollusing dumbbells (milk cans or syrup bottles without weights in them), students hold the stick in front of the body and the weight is left hanging at the end of the rope. The palms should be pointing downwards, with the arms starting to wind the rope using the stick so that the rope will be wrapped around the stick and the weight will be lifted up. Stop when the weight has reached the stick, then carefully stretch the rope back until it hits the floor again. The purpose of the wrist curl exercise is to strengthen the wrist. The third treatment isskippingcorrectly gradually starting from the front jump, skipping exercise to increase hand speed. Treatment of the four exercisesShutle Run to train body agility. Fifth treatmentPush Up exercises combined with changing the distance between the palms, opening or clenching the palms or using the fingers, changing the distance between the legs and changing the height of the body using a chair aid to increase hand strength. The sixth treatment is a Zig Zag running exercise to improve body agility. Seventh treatmentexercise Shutle Run modification to train body agility. The eighth treatment of $\mathrm{Zig} \mathrm{Zag}$ running exercises to improve body agility. The ninth treatment is Chair Dip to increase arm muscle strength. The tenth treatment is the Dumble Curl exercise for mincrease hand muscle strength. The eleventh treatment is the Seated Row exercise, students start by sitting on a chair while holding the cable, while the feet are placed on the footing with slightly bent knees while bending the body, then students pull the cable slowly until it touches the stomach and feel the pressure that occurs in the back muscles and then puffs out the body. and straighten your back, this exercise is useful for increasing strengthto train the back shoulder muscles and also the middle back muscles. The twelfth treatment is Pull up exerciseto increase strength for the back and abdominal muscles. The thirteenth treatment is the 
Hover rotation exerciseto improve the ability of the arm and shoulder muscles. The last treatment is Plyometric exercises to increase muscle strengthand faster in giving the effect of muscle contraction. In this experiment, it is done manually or not using tools, here the researcher requires a minimum of 2 people in every multiball exercise that is carried out, where 1 person is a feeder and 1 person is a player. scores obtained by students.

\section{Data Design or Analysis}

The research design used in this research isone group pretest posttest designnamely experimental research conducted on only one group selected randomly. This sample was given treatment for 16 meetings. The training given is for 4 weeks, each week is given 4 meetings. Variable is an important element in a study, without a variable, the researcher cannot carry out research (Punanji, 2012)

If the research design is complex or the stimulus requires a detailed description, additional subsections or subheadings to divide the subsections may be needed to help the reader find specific information.

\section{RESULTS}

Data collection was carried out at SMA Negeri 7 Bengkulu City. The population and sample of the study were the number of students who took part in extracurricular activities as many as 16 students. Before doing multiball exercises at SMA Negeri 7 Bengkulu City, the students were first recorded, after that the research was carried out, on the first day of the pretest student meeting the results obtained were still below the average of 37, after that treatment was carried out at the second meeting until the first meeting. the fifteenth, at the time of treatment it was seen that students had increased from the initial treatment to the end, and at the last meeting students were asked to do a posttest, after the posttest, the students' scores were much higher than the pretest, for comparison of the students' average pretest and posttest scores. can be seen in table 1 below:

Table 1. Average Value of Student Pretest

\begin{tabular}{lc}
\multicolumn{2}{c}{ and Posttest } \\
\hline \multicolumn{2}{c}{ Student Average } \\
\hline Pretest & 37 \\
\hline Posttest & 85 \\
\hline
\end{tabular}

From the table below, it can be obtained data for the pretest (without treatment) with the number of children as many as 16 students, the minimum score was 28 , the maximum score was 42.7, the average value was 36.8 and the standard deviation obtained by students was 3.79. After being treated for 16 meetings, the minimum student score was 81.3 , the maximum score was 92.0 , the average value was 86.33 and the standard deviation was 2.82 . From these data the researchers obtained significant results, the vulnerable values obtained before treatment and after being given treatment increased. So it can be said that multiball practice has an influence on the accuracy of forehand strokes in table tennis extracurricular students at SMA Negeri 07 Bengkulu City.. The data can be seen in table 2 and graph 2 of the students' pretest and posttest data

Table 2. Pretest and posttest data

\begin{tabular}{|c|c|c|c|c|c|}
\hline & $\mathbf{N}$ & Min & Max & mean & $\begin{array}{c}\text { Std. } \\
\text { Deviation }\end{array}$ \\
\hline Pre_child & 16 & 28.0 & 42.7 & 36,831 & 3.7977 \\
\hline Post_child & 16 & 81.3 & 92.0 & 86,331 & 2.8241 \\
\hline
\end{tabular}




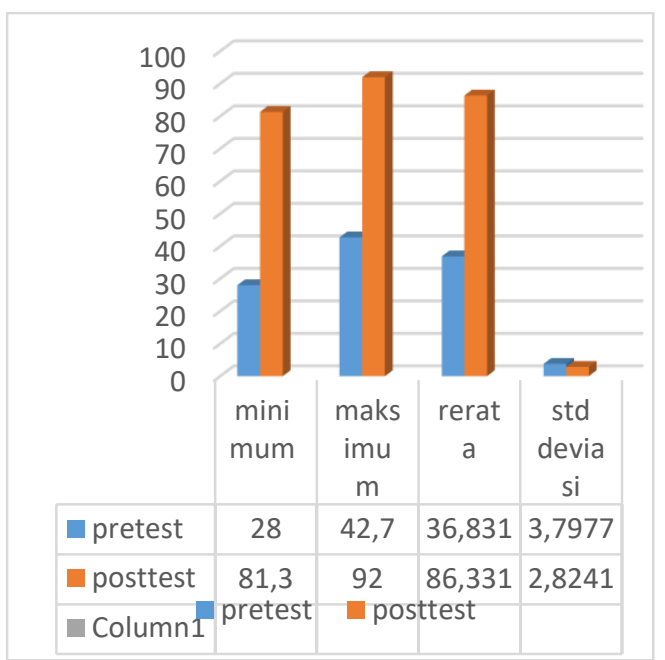

Grafik 1. Pretest dan posttest

\section{a) Normality test}

The purpose of the normality test is that the data obtained from the test results are actually normal or not. Test the normality of the data using ChiSquare. The rule used to determine whether or not a distribution is normal is if the significance value is greater than 0.05 ( $\mathrm{sig}>0.05)$, then it is normal and if the significance value is less than 0.05 $(\operatorname{sig}<0.05)$ then the data is said to be not. normal, and to find the normality test can use the equation below, or use the SPPS application.

Table 3. Data Normality Test Results

Shapiro-Wilk

\begin{tabular}{cccc} 
& Statistics & df & Sig. \\
\hline Pre_child & .956 & 16 & .588 \\
\hline Post_child & .974 & 16 & .902 \\
\hline
\end{tabular}

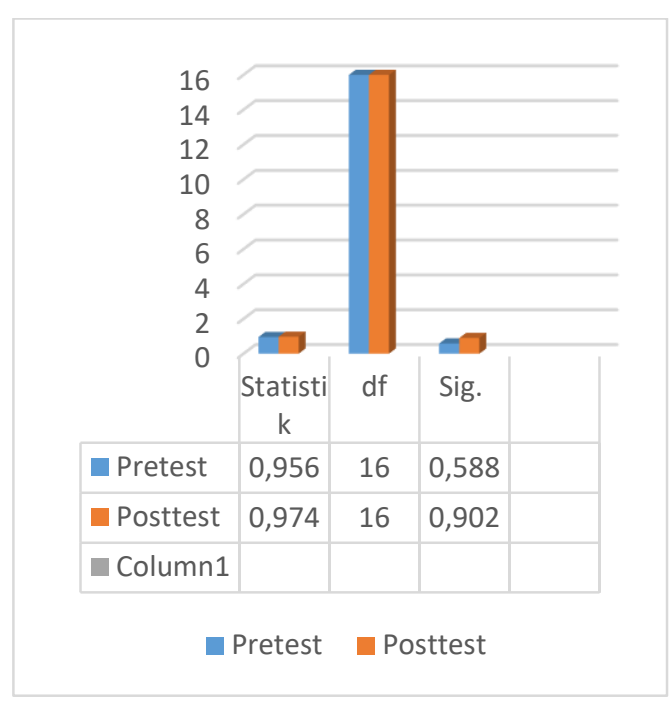

Grafik 2. Normality test

In table 3 and graph 2, the significance value (p) in the Shapiro-Wilk test is 0.588 ( $p>0.05$ ), so based on the Shapiro-Wilk normality test, the data is normally distributed. The significance value (p) of the posttest on the Kolmogrov-Smirnov test is 0.2 ( $\mathrm{p}>$ 0.05 ), so based on the KolmogrovSmirnov normality test the data is normally distributed. The significance value $(\mathrm{p})$ in the Shapiro-Wilk test is 0.902 ( $p>0.05$ ), so based on the Shapiro-Wilk normality test, the data are normally distributed.

\section{b) $\mathrm{T}$ test}

In a study that aims to compare two paired samples (such as pretest and posttest scores), hypothesis testing is obtained by using paired samples statistics. For this test, it can be done if the main condition is that the research data is normally distributed, and in the normality test above it can be seen that the data is normally distributed, then hypothesis testing with paired samples statistics test can be carried out. 
Table 4. Paired Samples Statistics

\begin{tabular}{ccccc}
\hline & & & Std. & Std. \\
& & & & \\
& mean & N & Deviation & Error Mean \\
\hline Pre_child & & & & \\
& 36,831 & 16 & 3.7977 & .9494 \\
\hline Post_child & 86,331 & 16 & 2.8241 & .7060 \\
\hline
\end{tabular}

Table 4. above shows a summary of the statistical results of the two samples studied, namely the pretest and posttest. For the pretest value, the average learning outcome or mean is 36,831, while the posttest obtained a value of 86,331 with the number of respondents or students as a sample, namely 16 students. For the standard deviation value at the pretest is 3.7977 , while the posttest is 2.8241 , and finally the standard error mean for the pretest is 0.9494 and the posttest is 0.7060 . because the average value of learning outcomes in the Pre-test is 36,831 < Post-test 86,331, it means that descriptively there is a difference in the average learning outcomes between the Pre-test and Post-test. Furthermore, to prove whether there is a relationship between the two data or the relationship between the Pre-test and Post-test variables, then,

Table 5. Paired Samples Correlations

\begin{tabular}{cccc} 
& N & Correlation & Sig. \\
\hline Pre_child \& & & & \\
Post_child & 16 & .404 & -121
\end{tabular}

Based on table 5. above, it is known that the coefficient value is 0.404 with a significance value of 0.121 , because the value of Sig. $0.121>0.05$ probability, it can be said that there is no relationship between the Pre-test variable and the Post-test variable. To determine whether or not there is an effect of multiball practice on the accuracy of forehand strokes in table tennis extracurricular students at SMA Negeri 7 Bengkulu City, we use the following equation:

$$
\mathrm{S} 2 \mathrm{D}=\left[\sum \mathrm{D} 2-\left(\left(\sum \mathrm{D}\right) 2 / \mathrm{n}\right)\right] /[\mathrm{n}-1]
$$

By using the above equation, it is obtained that $\mathrm{t}$ count is 142.13 and $\mathrm{t}$ table is 2.13145 which is obtained from the Distribution Percentage Point table (df $=1-40)$ so that $t$ count $>t$ table, then $\mathrm{H} 0$ is rejected and $\mathrm{H} 1$ is accepted according to the guidelines (Singgih , 2014).

\section{Information :}

a) If the value of Sig. (2-tailed) $<0.05$, then $\mathrm{HO}$ is rejected and $\mathrm{Ha}(\mathrm{H} 1)$ is accepted

b) On the other hand, if the value of Sig. (2-tailed) $>0.05$, then $\mathrm{HO}$ is accepted and $\mathrm{Ha}(\mathrm{H} 1)$ is rejected

So it can be concluded that the value of Sig. (2-tailed) $>0.05$, then $\mathrm{H} 0$ is accepted and $\mathrm{Ha}(\mathrm{H} 1)$ is rejected, which means that there is an effect of multiball practice on the accuracy of forehand strokes in table tennis extracurricular students at SMA Negeri 7 Bengkulu City

\section{CONCLUSION}

Based on the results of research and discussion in the previous chapter, the following conclusions can be drawn:

a) Pretest results obtained by students are still below the average value of very poor (category E), because they have not been treated.

b) Posttest results obtained by students 
have increased from very poor scores (category E) Pretest to very good (category A) after treatment.

c) There is the effect of multiball training on the accuracy of table tennis forehand strokes for extracurricular participants in 2020/2021 at SMA Negeri 7 Bengkulu City.

\section{SUGGESTION}

a) Teachers and students are expected to have a higher spirit in every table tennis extracurricular.

b) For teachers and students are expected to increase creativity in performing the accuracy of forehand strokes in order to maintain or improve the accuracy that students already have.

c) Teachers and students are expected to be able to increase the variety in doing forehand strokes in the table tennis game.

\section{REFERENCES}

Achmad, Sandi (2017). The Relationship between Eye-Hand Coordination, Arm Strength and Achievement Motivation with Forehand Accuracy in Table Tennis. Journal. West Nusa Tenggara. LITPAM.

Arikunto, Suharsimi. (2010). Research Procedure A Practical Approach (Revised Edition 2010). Jakarta :Rineka Cipta.

Daulay, Basyaruddin (2014). Sports Science. Medan : State University of Medan.

Department of Culture and National Education (2013). Guidebook for Training and Education of Sports Clubs for Table Tennis Games. Lubuk Agung : Bandung.

Hasanah, M. (2013). The Effect of Plyometric Depth Jump and Jump To Box Exercises on Power Limb
Muscles in Volleyball Athletes at Tugumuda Club Semarang City (Doctoral dissertation, Semarang State University).

Hsin-Hsueh Huang, et al (2012). The Dynamical Analysis Of Tale Tennis Forehand And Backhad Drives, (Online) Accessed July 20, 2020.

Juniarisca, Dwi and Andrijanto, Dony (2017). Table Tennis Game. Surabaya: Unesa University Press

Mulia, Fuji (2013). Definition of Exercise according to Experts . http://www.trigonalworld.com/201 3/04/pengertian-rehearsalaccording-ahli.html

Pujianto, D. \& Insanistyo. (2013). Teaching Materials for Physical Education Research Fundamentals. Bengkulu: FKIP Bengkulu University.

Punanji Setyosari. (2012). Educational Research and Development Methods. Jakarta : Kencana Pranada Media Group.

Santi \& Nurdianti et al (2018). The Effect of Multiball Practice Methods and Exercises with Other Players on Forehand Drive Accuracy in Table Tennis Extracurricular Students at SMA Negeri 1 Jalancagak in 2018. Scientific Journal, 4 (2) 25-29.

Sugiyono (2013). Qualitative Quantitative Research Methods, and R\&D. Bandung : Alphabeta.

Sukadiyanto \& Muluk, 2011. Introduction to Physical Training Theory and Methodology. Bandung: Lubuk Agung

Sulaksono, G. (2015). The Effect of Plyometric Depth Jump Exercises on Increasing Limb Muscle Explosive Power in Smash in Volleyball Game for Vocational High School Students Darus 
Salam, Kediri City, 2014/2015

Academic Year.

Ubaidah, Sity (2017). Extracurricular Management in Improving School

Quality.Journal of Sports, 3 (1) 153-154.

Wiyani, Novan Ardy (2013). Fostering Character Education in Elementary Schools (Concepts, Practices and Strategies. Jogjakarta: Ar-Ruzz

Media.Kurniawan, Feri (2012). Sports Knowledge Smart Book. Jakarta: Warriors 